\title{
PENGARUH PROSES PEMBERIAN PEMBIAYAAN DAN PREFERENSI TERHADAP KEPERCAYAAN NASABAH PEMBIAYAAN MULTIJASA PADA PT. BANK PEMBIAYAAN RAKYAT SYARIAH (BPRS) FAJAR SEJAHTERA BALI
}

\author{
Anifatin Aniroh ${ }^{1}$, Ely Mansur $^{2}$, Raden Agrosamdhyo ${ }^{3}$ \\ ${ }^{1,2,3}$ Program Studi Ekonomi Syariah, Sekolah Tinggi Agama Islam Denpasar Bali, \\ Denpasar, Indonesia
}

e-mail: \{anifatinaniroh@gmail.com, elymansur1973@gmail.com, ragrosamdhyo@gmail.com\}

\begin{abstract}
ABSTRAK
Perilaku seseorang dalam memutuskan untuk memilih produk dalam pembiayaan multijasa di setiap lembaga keuangan pasti dipengaruhi oleh rasionalitas ekonomi yakni bagi hasil, fasilitas, pelayanan, kemudahan, kenyamanan dan keamanan transaksi. Karena sebagai indentitas dan juga sebagai langkah untuk menarik nasabah yang pada pencapaiannya yaiu kepercayaan nasabah. Rumusan masalah penelitian ini adalah (1) Apakah proses pemberian pembiayaan dapat berpengaruh terhadap kepercayaan nasabah pembiayaan multijasa pada PT. Bank Pembiayaan Rakyat Syariah Fajar Sejahtera Bali? (2) Apakah preferensi dapat berpengaruh terhadap kepercayaan nasabah pembiayaan multijasa? (3) Apakah proses pemberian pembiayaan dan preferensi dapat berpengaruh terhadap kepercayaan nasabah pembiayaan multijasa? Tujuan penelitian ini adalah untuk mengetahui (1) pengaruh proses pemberian pembiayaan terhadap kepercayaan nasabah pembiayaan multijasa (2) pengaruh preferensi terhadap kepercayaan nasabah pembiayaan multijasa (3) pengaruh proses pemberian pembiayaan dan preferensi terhadap kepercayaan nasabah pembiayaan multijasa. Metode penelitian ini adalah pendekatan kuantitatif deskriptif dengan sumber data yang digunakan berupa data primer dan sekunder. Populasi penelitian yaitu, nasabah pembiayaan multijasa PT. Bank Pembiayaan Rakyat Syariah (BPRS) Fajar Sejahtera Bali dengan teknik pengumpulan data melalui angket/kuesioner dan dokumentasi. Teknik analisis data yang digunakan adalah uji regresi linier berganda, uji parsial, uji simultan dan uji determinan dengan menggunakan SPSS (Statistical Package For Social Seince) versi 24. Berdasarkan hasil perhitungan uji regresi linier berganda dengan persamaan $\mathrm{Y}=5,719$ $+0.134 \mathrm{X}_{1}+0,634 \mathrm{X}_{2}+\mathrm{e}$ hasil koefisien korelasi secara terpisah diperoleh X1 5C sebesar 0,134 dengan nilai signifikan $0,037<0,05$ sedangkan variabel X2 preferensi sebesar 0,634 dengan nilai signifikan $0,000<0,05$ dengan secara simultan 30,761 dengan signifikan 0,00 besarnya nilai koefisien determinasi tersebut menunjukan adanya pengaruh antara 5C dan preferensi terhadap kepercayaan nasabah pembiayaan multijasa di PT. Bank Pembiayaan Rakyat Syariah (BPRS) Fajar Sejahtera Bali baik secara parsial atau terpisah maupun secara simultan.
\end{abstract}

Kata kunci: Proses Pemberian Pembiayaan, Preferensi, Kepercayaan Nasabah.

\begin{abstract}
A person's behavior in deciding to choose a product for multi-service financing at any financial institution is definitely influenced by economic rationality, namely profit sharing, facilities, services, convenience, convenience and security of transactions. Because as an identity and also as a step to attract customers whose achievements are customer trust. The formulation of the research problems are (1) whether the process of providing financing can affect the trust of multi-service financing customers in PT. Fajar Sejahtera Bali Sharia People's Financing Bank? (2) Can preferences affect customer trust in multi-service financing? (3) Can the process of providing financing and preferences affect customer trust in multi-service financing? The purpose of this study was to determine (1) the effect of the process of providing financing on customer trust in multi-service financing (2) the effect of preference on customer trust in multi-service financing (3) the effect of the process of providing financing and preferences on customer trust in multi-service financing. This research method is a descriptive quantitative approach with data sources used in the form of primary and secondary data. The study population, namely, multi-service financing customers of PT. Sharia People's Financing Bank (BPRS) Fajar Sejahtera Bali with data collection techniques through questionnaires / questionnaires and documentation. The data analysis technique used is multiple linear regression test, partial test, simultaneous test and determinant test using SPSS (Statistical Package for Social Seince) version 24. Based on the results of the calculation of multiple linear regression with the equation $\mathrm{Y}=5.719$ $+0.134 \mathrm{X} 1+0.634 \mathrm{X} 2+\mathrm{e}$, the results of the correlation coefficient are separately obtained by X1 5C of 0.134 with a significant value of $0.037<0.05$ while the variable $\mathrm{X} 2$ preference is 0.634 with a significant value of $0.000<0,05$ with 30.761 simultaneously with a significant 0.00 of the value of the coefficient of determination shows the influence between 5C and preferences on customer trust in multi-service financing in PT. Sharia People's Financing Bank (BPRS) Fajar Sejahtera Bali either partially or separately or simultaneously.
\end{abstract}


Keywords: Financing Provision Process, Preference, Customer Trust

\section{PENDAHULUAN}

Sistem dan prosedur pembiayaan merupakan cara- cara dalam melaksanakan transaksi pembiayaan yang telah terjadi dengan ketentuan- ketentuan yang telah di tetapkan dengan tujuan untuk menghindari kesalahfahaman dan cara pelaksanaan dalam melakukan pembiaayan. Pada akhirnya prosedur akan menjadi pedoman bagi suatu organisasi dalam menentukan aktivitas apa saja yang harus dilakukan untuk menjalankan suatu fungsi tertentu. Prosedur adalah suatu kegiatan klerikal, biasanya melibatkan beberapa orang dalam suatu departemen atau lebih, yang dibuat untuk menjamin penengan secara seragam transaksi perusahaan yang terjadi berulangulang. ${ }^{1}$ Perilaku seseorang dalam memutuskan untuk memilih produk dalam pembiayaan multijasa di setiap lembaga keuangan pasti dipengaruhi oleh rasionalitas ekonomi dan motivasi seperti keuntungan yang didapatkan yakni bagi hasil, fasilitas, pelayanan, kemudahan, kenyamanan dan keamanan transaksi. Setiap lembaga pasti mempunyai ciri tertentu dalam beroperasi. Karena sebagai indentitas dan juga sebagai langkah untuk menarik nasabah yang pada pencapaiannya yaiu kepercayaan nasabah.

Untuk itu kepercayaan pelanggan sebagai suatu amanat hendaknya tidak disiasiakan dengan memberikan pelayanan secara profesional melalui pegawai yang bekerja sesuai dengan bidangnya dan mengerjakan pekerjaannya secara cepat dan tepat, sebagaimana yang dinyatakan dalam surat Q.S Al Maidah ayat 1 .

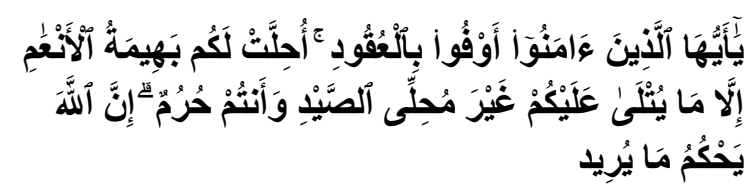

Hai orang-orang yang beriman, penuhilah aqad-aqad itu. Dihalalkan bagimu binatang ternak, kecuali yang akan dibacakan kepadamu. (Yang demikian itu) dengan tidak menghalalkan berburu ketika kamu sedang mengerjakan haji.

${ }^{1}$ Mulyadi, Sistem Akuntansi, Edisi ke-3, Cetakan ke-5. (Jakarta: Penerbit Salemba Empat, 2010), h. 5
Sesungguhnya Allah menetapkan hukumhukum menurut yang dikehendakiNya. (Qs. Al Maidah:1). ${ }^{2}$

Kutipan ayat tersebut menjelaskan mengenai dapat dikaitkan dengan kepercayaan nasabah, yang mana nasabah sudah setia dan percaya utuk menitipkan dananya ataupun meminjam dana. Kepercayaan merupakan sebuah keyakinan dari salah satu pihak mengenai maksud dan perilaku yang ditujukan kepada pihak yang lainnya, dengan demikian kepercayaan konsumen didefinisikan sebagai suatu harapan konsumen bahwa penyedia jasa bisa dipercaya atau diandalkan dalam memenuhi janjinya.

Bank merupakan suatu lembaga keuangan yang kegiatan intinya di bidang keuangan, yakni menarik dan menyalurkan dana ke masyarakat. Bank juga sebagai lembaga intermediasi antara masyarakat yang membutuhkan dana di satu pihak dengan pihak lain yang mengalami kelebihan dana. Di indonesia terdapat 2 jenis bank, yaitu bank konvensional dan bank syariah. Bank Pembiayaan Rakyat Syariah (BPRS) sebagai salah satu lembaga kepercayaan masyarakat yang kegiatan usahanya berdasarkan prinsip syariah. Keberadaan BPRS dimaksudkan untuk dapat memberikan layanan perbankan secara cepat, mudah dan sederhana kepada masyarakat khususnya pengusaha kecil, menengah, dan besar.

Salah satu pelayanan yang diberikan yakni memberikan pembiayaan kepada msayarakat yang membutuhkan dana. Kegiatan pembiayaan merupakan kegiatan menyalurkan dana dengan berbagai sistem yaitu meliputi jual beli, kerja sama dan juga jasa. Oleh karena itu kegiatan pembiayaan harus dilakukan secara sistematis serta di perlukan mekanisme secara prosedur yang baik untuk mencapai layanan terpadu yaitu kepercayaan nasabah.

Perilaku seseorang dalam memutuskan untuk memilih produk dalam pembiayaan multijasa di setiap lembaga keuangan pasti dipengaruhi oleh rasionalitas ekonomi dan motivasi seperti keuntungan yang didapatkan

\footnotetext{
${ }^{2}$ Mirchandani, Alqur'anku Dengan Waqaf Ibtida Tajwid Blok Warna, (Jakarta: Lautan Lestari), h. 106
} 
yakni bagi hasil, fasilitas, pelayanan, kemudahan, kenyamanan dan keamanan transaksi. Tetapi apakah prosedur pembiayaaan mempengaruhi perilaku kepercayaannya, inilah yang perlu dilakukan penelitian lebih lanjut. Setiap lembaga pasti mempunyai ciri tertentu dalam beroperasi. Karena sebagai indentitas dan juga sebagai langkah untuk menarik nasabah yang pada pencapaiannya yaiu kepercayaan nasabah.

Sistem dan prosedur pembiayaan merupakan cara- cara dalam melaksanakan transaksi pembiayaan yang telah terjadi dengan ketentuan- ketentuan yang telah di tetapkan dengan tujuan untuk menghindari kesalahfahaman dan cara pelaksanaan dalam melakukan pembiaayan. Prosedur adalah serangkaian titik rutin yang diikuti dalam melaksanakan suatu wewenang fungsi dan operasional. $^{3}$

Sebelum dilakukannya pembiayaan maka bank harus merasa percaya bahwa pembiayaan yang diberikan kepada nasabah akan kembali. Kepercayaan tersebut didapatkan dari hasil penilain pembiayaan sebelum pembiayaan dilakukan kepada nasabah. Penilaian pembiayaan dapat dilakukan sebelum memberikan pembiayaan untuk memperoleh kepercayaan tentang nasabahnya yang ingin melakukan pembiayaan, dengan cara menjalankan langkah penilaian yang benar-benar dan akurat agar bank lebih menjadi hati-hati dalam memberikan pembiayaan kepada nasabah

Berdasarkan dari hasil penelusuran yang sudah dilakukan terhadap sumber kepustakaan dan penelitian terdahulu, perbedaan penelitian ini adalah perbedaan dari pokok pembahasan. Peneliti melakukan penelitian pada instansi perbankan syariah di wilayah Badung tepatnya di PT. Bank Pembiayaan Rakyat Syariah Fajar Sejahtera Bali. Tujuan dari penelitian ini adalah untuk mengetahui bagaimana pengaruh prosedur pembiayaan multijasa dan preferensi terhadap kepercayaan nasabah. Dari latar belakang ini penulis tertarik untuk memilih dan menulis mengenai kepercayaan calon nasabah. Untuk itu, penulis mengambil judul penelitan

${ }^{3}$ Narko. Sistem Akuntansi. Edisi 5. (Yogyakarta: Yayasan Pustaka Nusantara, 2007), h. 3
"Pengaruh Proses Pemberian Pembiayaan Dan Preferensi Terhadap Kepercayaan Nasabah Pembiayaan Multijasa Pada PT. Bank Pembiayaan Rakyat Syariah (BPRS) Fajar Sejahtera Bali”.

Rumusan permasalahan dalam penelitian ini adalah: " Apakah proses pemberian pembiayaan dapat berpengaruh terhadap kepercayaan nasabah pembiayaan multijasa pada PT. Bank Pembiayaan Rakyat Syariah Fajar Sejahtera Bali?; Apakah preferensi dapat berpengaruh terhadap kepercayaan nasabah pembiayaan multijasa pada PT. Bank Pembiayaan Rakyat Syariah Fajar Sejahtera Bali?; Apakah prosedur pembiayaan multijasa dan preferensi dapat berpengaruh terhadap kepercayaan nasabah multijasa pada PT. Bank Pembiayaan Rakyat Syariah Fajar Sejahtera Bali?"

Untuk mendapatkan jawaban dari fokus permasalahan dalam penelitian tersebut, maka peneliti melakukan kajian melalui metode kuantitatif deskriptif sebagaimana paparan pada bagian metode penelitian dalam artikel ini.

Tujuan penelitian ini adalah untuk mengetahui pengaruh proses pemberian pembiayaan dan preferensi terhadap kepercayaan nasabah multijasa pada PT. Bank Pembiayaan Rakyat Syariah Fajar Sejahtera Bali.

\section{METODE PENELITIAN}

Penelitian ini menggunakan metode kuantitatif deskriptif dengan pendekatan kuantitatif. Alasan digunakannya pendekatan ini karena peneliti ingin lebih memahami secara lebih mendalam mengenai pengaruh proses pemberian pembiayaan dan preferensi tehadap kepercayaan nasabah pembiayaan multijasa. Selain itu dengan menggunakan metode kuantitatif, data yang didapat akan lebih lengkap, lebih mendalam, kredibel, dan bermakna. Jenis penelitian kuantitatif yang dipilih untuk penelitian ini adalah penelitian deskriptif. Metode deskriptif tersebut digunakan untuk mendeskripsikan suatu peristiwa yang telah terjadi untuk mendapatkan suatu fakta yang berkaitan dengan menguraikan secara mendalam bagaimana proses pemberian pembiayaan dan preferensi tehadap kepercayaan nasabah pembiayaan multijasa. 
Penentuan sampel dalam penelitian ini menggunakan rumus slovin. Pemilihan informan dilakukan karena mungkin saja peneliti telah memahami bahwa informasi yang dibutuhkan dapat diperoleh dari satu kelompok sasaran tertentu yang mampu memberikan informasi yang dikehendaki karena mereka memang memiliki informasi seperti itu dan mereka memenuhi kriteria yang ditentukan oleh peneliti. Sampel merupakan bagian dari jumlah dan karakteristik yang dimiliki oleh populasi tersebut. ${ }^{4}$

Untuk mendapatkan data atau informasi, digunakan teknik penyebaran angket/ kuesioner, yaitu pengumpulan data yang dilakukan melalui penyebaran pertanyaan yang disusun dalam satu kumpulan kepada responden. Bentuk kuesioner bersifat tertutup yaitu responden diberi alternative pilihan jawaban pada setiap pertanyaan. Seluruh variabel akan diukur menggunakan skala likert dengan skala 1 sampai 5. Penulis mengadakan penelitian secara teliti terlebih dahulu situasi yang ada di PT. BPRS Fajar Sejahtera Bali serta mencatat situasi kerja dan kegiatan lainnya secara sistematis.

Teknik dalam menguji keabsahan data yang di peroleh, peneliti menggunakan teknik SPSS (Statistical Package For Social Seince) versi 24. Teknik analisis data yang digunakan adalah uji regresi linier berganda, uji parsial, uji simultan dan uji determinan. Dengan melakukan pengecekan data kembali pada sumber yang sama, diharapkan mendapat data yang lebih akurat yang mana menggunakan teknik pengambilan data yang berbeda, misalnya menggunakan teknik observasi dan wawancara.

Dalam data kuantitatif data yang dikumpulkan seharusnya harus akurat, up to date, komprehensif dan relevan bagi persoalan atau permasalahan yang diteliti.Penggunaan data primer lebih diutamakan daripada penggunaan data sekunder. Jenis-jenis data tersebut dapat dikelompokan sebagai berikut : Data primer, yaitu data yang diperoleh peneliti dari sumber pertama baik individu maupun perseorangan, seperti hasil wawancara atau pengisian koesioner. Data sekunder, yaitu

${ }^{4}$ Sugiyono. Metode Penelitian Kuantitatif, Kualitatif, dan R\&D. (Bandung : Alfabeta, CV, 2017), h. 62 data yang telah diolah lebih lanjut dan disajikan baik oleh pihak pengumpul data primer maupun pihak lain.

Langkah-langkah analisis data dalam penelitian kuantitatif diskriptif ini, yaitu dengan; persiapan, tabulasi data, dan penerapan data sesuai pendekatan penelitian. Ada beberapa metode dalam pengumpulan data yaitu: Observasi, metode observasi merupakan suatu studi yang sistematis dan yang dipertimbangkan dengan baik melalui panca indra terhadap peristiwaperistiwa yang terjadi pada saat itu (pengamatan langsung). Kuesioner Instrument atau alat pengumpulan data adalah alat atau fasilitas yang digunakan oleh peneliti dalam mengumpulkan data agar pekerjaannya lebih mudah dan hasilnya lebih baik dalam arti lebih cermat, lengkap dan sistematis sehingga lebih mudah diolah.

Dalam pengumpulan data ini peneliti menggunakan kuesioner dengan jenis kuesioner tertutup yaitu responden tinggal menjawab pilihan pertanyaan yang telah ditentukan. Keabsahan Data, data akan valid apabila nasabah dalam mengisi kuesioner bersifat obyektif dan memahami pertanyaan yang ada. Nasabah yang dijadikan sampel pengambilan data dapat dipercaya dan paham akan adanya resiko pembiayaan bermasalah

\section{HASIL DAN PEMBAHASAN}

Hasil yang didapatkan berdasarkan data yang diperoleh melalui teknik pengumpulan data berupa observasi, penyebarab angket/kuesioner, serta studi kepustakaan mengenai prosedur pembiayaan multijasa dan preferensi dapat berpengaruh terhadap kepercayaan nasabah multijasa dengan studi kasus di PT. Bank Pembiayaan Rakyat Syariah Fajar Sejahtera Bali yang dilakukan oleh penulis, maka dapat dipaparkan hasil penelitian dan pembahasan sebagai berikut:

\section{Proses Pemberian Pembiayaan}

Sistem dan prosedur pembiayaan merupakan cara- cara dalam melaksanakan transaksi pembiayaan yang telah terjadi dengan ketentuan- ketentuan yang telah di tetapkan dengan tujuan untuk menghindari kesalahfahaman dan cara pelaksanaan dalam melakukan pembiaayan. Senada dengan yang disampaikan oleh Bapak Handy selaku For Rich Marketing:

1. Pertama mengisi form, melengkapi syarat2 
2. Kemudaian, dilakukan pengecekan slik BI Checking

3. Pengechekan kelengkapan persyaratan di bagian Management Resiko

4. Pengecekan legalitas jaminan di bagian legal

5. Kemudian berdasarkan hasil pengechekan yg sudah sesuai, baru AO menyiapkan analisa dan dokumen2 pengajuan

6. Komite dengan dewan direksi

7. Jika disetujui, pengajuan siap dicairkan. ${ }^{5}$

Tahapan demi tahapan dilakukan oleh bank syariah dalam menganalisis kelayakan nasabah dalam mendapatkan pembiayaan. Selain proses pemberian pembiayaan, faktor waktu dalam pencairan pembiayaan juga berpengaruh dalam kepercayaan nasabah untuk melakukan pembiayaan. Yang disampaikan oleh Bapak Handy selaku For Rich Marketing:

"Untuk normalnya bisa seminggu hingga 2 minggu. yg bikin lama suatu proses juga selain kelengkapan yg belum segera2 dilengkapi oleh calon nasabah juga dikarenakan faktor antrian dari pengajuan yg sudah ada. Karena harus diperiksa2 oleh bagian2 devisi lain seperti bagian admin BI Checking, manajemen resiko dan legalitas hingga akhirnya bisa diterima oleh AO yg kemudian baru bisa dilanjutkan ke tahap komite sebagai penentu pengajuan dapat dicairkan atau tidak."

\section{Uji Validitas}

Uji validitas butir menggunakan rumus korelasi product moment dengan bantuan program IBM SPSS Statistic versi 24 yang secara otomatis menampilkan koefisien validitas masing-masing butir instrumen. Mengukur validitas dilakukan dengan melakukan korelasi antar skor butir pernyataan dengan total skor konstruk atau variabel. Yaitu dengan membandingkan nilai $r_{\text {hitung }}$ dengan $\mathrm{r}_{\text {tabel }}$ untuk degree of freedom $(\mathrm{df})=\mathrm{n}$ - dimana (n) adalah jumlah sampel penelitian. Jika $r_{\text {hitung }}$ $>r_{\text {tabel }}$ dan nilai positif maka butir atau penyataan atau indikator tersebut dinyatakan valid.

${ }^{5}$ Handy, For Rich Marketing PT. BPRS Fajar Sejahtera Bali, Wawancara Pribadi, Denpasar 24 September 2020

${ }^{6}$ Handy, For Rich Marketing PT. BPRS Fajar

Sejahtera Bali, Loc. Cit
Tabel 4.1 Hasil Uji Validitas

\begin{tabular}{|c|c|c|c|}
\hline Item & $\begin{array}{l}\text { Item Total } \\
\text { Corelation }\end{array}$ & $\begin{array}{c}r_{\text {tabel }} d f=(N-2) \\
d f=(61-2)=59\end{array}$ & Keterangan \\
\hline \multicolumn{4}{|c|}{$5 \mathrm{C}(\mathrm{X1})$} \\
\hline Item 1 & 0,539 & 0,252 & Valid \\
\hline Item 2 & 0,415 & 0,252 & Valid \\
\hline Item 3 & 0,527 & 0,252 & Valid \\
\hline Item 4 & 0,573 & 0,252 & Valid \\
\hline Item 5 & 0,514 & 0,252 & Valid \\
\hline Item 6 & 0,550 & 0,252 & Valid \\
\hline Item 7 & 0,384 & 0,252 & Valid \\
\hline Item 8 & 0,645 & 0,252 & Valid \\
\hline Item 9 & 0,513 & 0,252 & Valid \\
\hline Item 10 & 0,278 & 0,252 & Valid \\
\hline Item 11 & 0,580 & 0,252 & Valid \\
\hline Item 12 & 0,686 & 0,252 & Valid \\
\hline Item 13 & 0,783 & 0,252 & Valid \\
\hline Item 14 & 0,583 & 0,252 & Valid \\
\hline \multicolumn{4}{|c|}{ Preferensi (X2) } \\
\hline Item 15 & 0,720 & 0,252 & Valid \\
\hline Item 16 & 0,524 & 0,252 & Valid \\
\hline Item 17 & 0,678 & 0,252 & Valid \\
\hline Item 18 & 0,788 & 0,252 & Valid \\
\hline Item 19 & 0,823 & 0,252 & Valid \\
\hline Item 20 & 0,530 & 0,252 & Valid \\
\hline \multicolumn{4}{|c|}{ Kepercayaan Nasabah (Y) } \\
\hline Item 21 & 0,711 & 0,252 & Valid \\
\hline Item 22 & 0,514 & 0,252 & Valid \\
\hline Item 23 & 0,741 & 0,252 & Valid \\
\hline Item 24 & 0,614 & 0,252 & Valid \\
\hline Item 25 & 0,741 & 0,252 & Valid \\
\hline Item 26 & 0,715 & 0,252 & Valid \\
\hline Item 27 & 0,775 & 0,252 & Valid \\
\hline
\end{tabular}

Sumber : Data Primer Diolah dengan SPSS versi 24, 2020

Uji Reliabilitas

Uji reliabilitas berguna untuk menetapkan apakah instrumen yang dalam hal ini kuesioner dapat digunakan lebih dari satu kali, paling tidak oleh responden yang sama akan menghasilkan data yang konsisten. Tingkat validitas dapat diukur dengan program statistical package for social sciences 24 (SPSS 24).

${ }^{7}$ Sahid Raharjo "Cara Melakukan Uji Reabilitas Alpha Cronbach's dengan SPSS" (http://www.spssstatistik.com/2014/01/ujireliabilitas-alpha-spss.html diakses 24 Juni 2020) 
Tabel 4.2 Hasil Uji Reliabilitas

\begin{tabular}{|l|l|l|l|}
\hline Variabel & Pernyataan & $\begin{array}{r}\text { Cronburch } \\
\text { Alpha }\end{array}$ & Keputusan \\
\hline $5 \mathrm{C}$ & $\begin{array}{l}\text { Item 1 - Item } \\
14\end{array}$ & 0,823 & Reliabel \\
\hline Preferensi & $\begin{array}{l}\text { Item 15 - Item } \\
20\end{array}$ & 0,769 & Reliabel \\
\hline $\begin{array}{l}\text { Kepercayaa } \\
\mathrm{n} \\
\text { Nasabah }\end{array}$ & $\begin{array}{l}\text { Item 21 - Item } \\
27\end{array}$ & 0,815 & Reliabel \\
\hline
\end{tabular}

Sumber : Data Primer Diolah dengan SPSS versi 24,2020

Uji Normalitas

Uji normalitas dilakukan untuk mengetahui apakah data dariketiga variabel penelitian yang diperoleh berasal dari kata yang berdistribusi secara normal atau tidak. Untuk menguji normalitas dengan uji Kolmogorov - Smirnov. Dibantu dengan program SPSS. Hasil uji normalis dapat dilihat pada tabel di bawah ini :

Tabel 4.3 Hasil Uji Normalitas

\begin{tabular}{|c|c|c|}
\hline \multicolumn{3}{|c|}{ One-Sample Kolmogorov-Smirnov Test } \\
\hline & $\begin{array}{l}\text { Unstandardiz d } \\
\text { Residual }\end{array}$ \\
\hline \multicolumn{2}{|r|}{1} & 2 \\
\hline \multicolumn{2}{|l|}{$\mathrm{N}$} & 61 \\
\hline \multirow{2}{*}{$\begin{array}{l}\text { Normal } \\
\text { Parameters }\end{array}$} & Mean &, 0000000 \\
\hline & Std. Deviation & $\begin{array}{r}1,771462 \\
26\end{array}$ \\
\hline \multirow{3}{*}{$\begin{array}{l}\text { Most } \\
\text { Extreme } \\
\text { Differences }\end{array}$} & Absolute & 066 \\
\hline & Positive & 058 \\
\hline & Negative &,- 066 \\
\hline \multicolumn{2}{|c|}{ Test Statistic } &, 066 \\
\hline \multicolumn{2}{|c|}{ Asymp. Sig. (2-tailed) } &, $200^{\mathrm{c}, \mathrm{d}}$ \\
\hline \multicolumn{3}{|c|}{ a. Test distribution is Normal. } \\
\hline \multicolumn{3}{|c|}{ b. Calculated from data. } \\
\hline \multicolumn{3}{|c|}{ c. Lilliefors Significance Correction. } \\
\hline \multicolumn{3}{|c|}{$\begin{array}{l}\mathrm{d} \text {. This is a lower bound of the true } \\
\text { significance. }\end{array}$} \\
\hline
\end{tabular}

Sumber : Data Primer Diolah dengan SPSS versi 24, 2020

Berdasarkan uji normalitas Kolmogorov-Smirnov di dapatkan nilai sebesar $0,066>0,05$ sehingga dapat disimpulkan bahwa tes berdidtribusi normal.

\section{Uji Autokorelasi}

Uji Autokorelasi bertujuan untuk menguji apakah dalam suatu model regresi linier berganda terdapat korelasi antara residual pada periode ke-t denagn residual periode t-1 (sebelumnya). Cara yang digunakan untuk mendeteksi ada atau tidaknya autokorelasi maka dilakukan uji DurbinWatson.

\section{Tabel 4.5 Hasil Uji Autokorelasi}

\begin{tabular}{|c|c|c|c|c|c|}
\hline \multicolumn{6}{|c|}{ Model Summary $^{\mathbf{b}}$} \\
\hline Model & $\mathrm{R}$ & $\begin{array}{c}\mathrm{R} \\
\text { Square }\end{array}$ & $\begin{array}{c}\text { Adjuste } \\
\text { d R } \\
\text { Square }\end{array}$ & $\begin{array}{c}\text { Std. } \\
\text { Error } \\
\text { of the } \\
\text { Estima } \\
\text { te }\end{array}$ & $\begin{array}{l}\text { Durbin } \\
\text { Watson }\end{array}$ \\
\hline 1 &, $717^{\mathrm{a}}$ &, 515 & ,498 & 1,80175 & 1,847 \\
\hline
\end{tabular}

Sumber : Data Primer Diolah dengan SPSS versi 24, 2020

Dari output SPSS di atas diketahui bahwa:

- Uji Statistik

$$
\begin{aligned}
& (4-\mathrm{dw})>\mathrm{du}<\mathrm{dw} \\
& (4-1,847)>1,6904<1,847 \\
& 2,153>1,6904<1,1847
\end{aligned}
$$

Hasil perhitungan diatas bahwa tidak ada autokorelasi dalam model regresi yang digunakan dalam penelitian ini.

Uji Heteroskedastisitas

Tabel 4.6 Hasil Uji Heteroskedastisitas

\begin{tabular}{|c|c|c|}
\hline No & Variabel & Signifikansi \\
\hline $\mathbf{1}$ & $\mathbf{2}$ & $\mathbf{3}$ \\
\hline 1 & $5 \mathrm{C}$ & 0,823 \\
\hline 2 & Preferensi & 0,978 \\
\hline
\end{tabular}

Sumber : Data Primer Diolah dengan SPSS versi 24,2020

Dari tabel diatas dapat disimpulkan bahwa setelah dilakukan uji heteroskedastisitas menggunakan bantuan SPSS versi 24 variabel Proses Pemberian Pembiayaan menunjukkan nilai signifikansi 0,823 dan variabel preferensi menunjukkan nilai signifikansi 0,978 lebih besar dari 0,05 sehingga dapat dikatakan tidak terjadi heteroskedastisitas.

\section{Uji Multikolinearitas}

Salah satu cara untuk menyatakan uji multikolinearitas adalah dengan melihat nilai Variance Inflation Factor (VIF) dari hasil analisis data. Jika nilai VIF > 10 maka terjadi multikolinearitas dengan variabel bebas lainnya, sebaliknya jika nilai VIF $<10$ maka tidak terjadi persoalan multikolinearitas. Uji 
multikolinearitas dilakukan dengan program SPSS versi 24 dengan hasil:

Tabel 4.7 Hasil Uji Multikolinearitas

\begin{tabular}{|l|l|c|c|}
\hline \multirow{2}{*}{ Variabel } & \multicolumn{2}{c|}{ Collinearity Statistics } \\
\cline { 2 - 4 } & Tolerance & VIF \\
\hline \multirow{2}{|c|}{1} & 2 & 3 \\
\hline $5 \mathrm{C}$ &, 775 & 1,291 \\
\hline & Preferensi &, 775 & 1,291 \\
\hline
\end{tabular}

Sumber : Data Primer Diolah dengan SPSS versi 24, 2020

Dari tabel tersebut dapat disimpulkan bahwa nilai VIF variabel Proses Pemberian Pembiayaan dan preferensi sebesar $1,291<10$, maka dapat dikatakan tidak terjadi multikoleniaritas antar variabel bebas atau dependen.

\section{Anlisis Regresi Linier Berganda}

Teknik analisis regresi berganda adalah sebuah metode pendekatan untuk permodelan hubungan antara satu variabel dependen dan dua atau lebih variabel independen. Dalam uji hipoteisi ini terdapat pengaruh antara Proses Pemberian Pembiayaan dan preferensi terhadap kepercayaan nasabah PT. Bank Pembiayaan Rakyat Syariah Fajar Sejahtera Bali.

Tabel 4.8 Hasil Analisis Regresi Linier Berganda

\begin{tabular}{|c|c|c|c|c|c|}
\hline \multirow[t]{2}{*}{ Model } & \multicolumn{2}{|c|}{$\begin{array}{c}\text { Unstanda } \\
\text { rdized } \\
\text { Coeffic } \\
\text { ients }\end{array}$} & \multirow{2}{*}{$\begin{array}{c}\begin{array}{r}\text { Standardized } \\
\text { Coefficients }\end{array} \\
\text { Beta }\end{array}$} & \multirow[t]{2}{*}{$\mathrm{t}$} & \multirow[t]{2}{*}{ Sig. } \\
\hline & B & $\begin{array}{c}\text { Std. } \\
\text { Error }\end{array}$ & & & \\
\hline (Constant) & 5,719 & 3,690 & & 1,550 & , 127 \\
\hline $\begin{array}{l}5 \mathrm{C} \\
\text { (CHARA } \\
\text { CTER, } \\
\text { CAPACIT } \\
\text { Y, } \\
\text { CAPITAL } \\
\text { CONDITI } \\
\text { ON, } \\
\text { COLLAT } \\
\text { ERAL) }\end{array}$ & , 134 & ,063 & ,222 & 2,141 & ,037 \\
\hline Preferensi & ,634 & ,113 & ,585 & 5,626 &, 000 \\
\hline
\end{tabular}

Sumber : Data Primer Diolah dengan SPSS

versi 24, 2020

Persamaan garis regresi berdasarkan hasil di atas adalah sebagai berikut:

$\mathrm{Y}=\mathrm{a}+\mathrm{b}_{1} \mathrm{X}_{1}+\mathrm{b}_{2} \mathrm{X}_{2}+\mathrm{e}$

$\mathrm{Y}=5,719+0,134 \mathrm{X}_{1}+0,634 \mathrm{X}_{2}+\mathrm{e}$

$\mathrm{X}_{1}=$ Proses Pemberian Pembiayaan

$\mathrm{X}_{2}=$ Preferensi
Konstanta sebesar 5,719 menyatakan bahwa jika Proses Pemberian Pembiayaan dan Preferensi 0, maka Kepercayaan Nasabah 5,719. Koefisien regresi X1 sebesar 0,134 dan koefisien regresi X2 sebesar 0,634 menyatakan bahwa setiap pembahasan 1 skor pada masingmasing variabel akan meningkatkan Proses Pemberian Pembiayaan sebesar 0,134 sedangkan Preferensi 0,634.

Untuk analisis regresi linier berganda, harga koefisien korelasi X1 sebesar 0,134 sedangkan harga koefisien korelasi X2 sebesar 0,634 .

Uji t

Untuk melihat pengaruh variabel pengaruh prosedur pembiayaan multijasa dan preferensi terhadap variabel kepercayaan nasabah maka dilakukan uji hipotesis yaitu uji t. Pada tabel dapat dilihat hasil uji t dengan program SPSSversi 24. Menurut Imam Ghozali, uji statistik $\mathrm{t}$ pada dasarnya menunjukkan seberapa jauh pengaruh satu variabel independen secara individual dalam menerangkan variabel dependen. ${ }^{8}$

Tabel 4.9 Hasil Uji t

\begin{tabular}{|c|l|c|c|}
\hline No & Variabel & thitung & Signifikansi \\
\hline 1 & $5 \mathrm{C}$ & 2,141 & 0,037 \\
\hline 2 & Preferensi & 5,626 & 0,000 \\
\hline
\end{tabular}

Sumber : Data Primer Diolah dengan SPSS versi 24,2020

\section{Uji f}

Menurut ghozali, uji statistik F pada dasarnya menunjukkan apakah semua variabel independen atau variabel bebeas yang dimasukkan dalam model mempunyai pengaruh secara bersama-sama terhadap variabel dependen atau variabel terikat. ${ }^{9}$

Tabel 4.10 Hajil Uji f

\begin{tabular}{|c|c|c|c|c|c|}
\hline \multicolumn{6}{|c|}{ ANOVA $^{\text {a }}$} \\
\hline Model & $\begin{array}{c}\text { Sum } \\
\text { of } \\
\text { Square } \\
\text { s }\end{array}$ & df & $\begin{array}{c}\text { Mean } \\
\text { Square }\end{array}$ & F & Sig. \\
\hline
\end{tabular}

${ }^{8}$ Ghozali, Imam. Aplikasi Analisis Multivariate dengan Program IBM SPSS 21 Update PLS Regresi. (Semarang: Badan Penerbit Universitas Diponegoro,2013), h. 98

${ }^{9}$ Ghozali, Imam. Aplikasi Analisis Multivariate dengan Program IBM SPSS. (Yogyakarta: Universitas Diponegoro, 2012) h, 98 


\begin{tabular}{|l|l|c|c|c|c|c|}
\hline \multirow{2}{*}{1 Regression } & 199,715 & 2 & 99,858 & 30,761 &, $000^{\mathrm{b}}$ \\
\cline { 2 - 6 } & Residual & 188,285 & 58 & 3,246 & & \\
\hline & Total & 388,000 & 60 & & & \\
\\
a. Dependent Variable: Kepercayaan Nasabah \\
\hline \\
b. Predictors: (Constant), Preferensi, 5C (CHARACTER, \\
CAPACITY, CAPITAL, CONDITION, COLLATERAL)
\end{tabular}

Sumber : Data Primer Diolah dengan SPSS

versi 24, 2020

Berdasarkan hasil uji $F_{\text {hitung }}$ yang diperoleh dari hasil regresi dengan bantuan SPSS yang dimana $F_{\text {hitung }}$ sebesar 30,761 dengan nilai signifikansi 0,00 maka Ho ditolak $\mathrm{Ha}$ diterima. Ini berarti variabel Proses Pemberian Pembiayaan, Preferensi berpengaruh signifikan secara simultan terhadap variabel Kepercayaan Nasabah.

Koefisien Determinasi $\left(\mathbf{R}^{2}\right)$

Tabel 4.11 Hasil Koefisien Determinasi

\begin{tabular}{|c|c|c|c|c|r|}
\hline \multicolumn{7}{|c|}{ Model Summary $^{\text {b }}$} \\
\hline Model & $\mathrm{R}$ & $\begin{array}{c}\mathrm{R} \\
\text { Square }\end{array}$ & $\begin{array}{c}\text { Adjusted R } \\
\text { Square }\end{array}$ & $\begin{array}{c}\text { Std. Error } \\
\text { of the } \\
\text { Estimate }\end{array}$ & $\begin{array}{c}\text { Durbin- } \\
\text { Watson }\end{array}$ \\
\hline 1 &, $717^{\mathrm{a}}$ &, 515 &, 498 & 1,80175 & $\begin{array}{r}1,8 \\
47\end{array}$ \\
\hline \multicolumn{7}{|l|}{} \\
a. Predictors: (Constant), Preferensi, 5C \\
\hline \multicolumn{5}{|l}{ b. Dependent Variable: Kepercayaan Nasabah } \\
\hline
\end{tabular}

Sumber : Data Primer Diolah dengan SPSS versi 24, 2020

Koefisien Determinasi $\left(\mathrm{R}^{2}\right)$ pada intinya mengukur seberapa jauh kemungkinan model dalam menerangkan variasi variabel dependen. Dihitung dengan melihat $\mathrm{R}^{2}$ pada tabel 4.11 sebesar 0,515 dikalikan dengan $100 \%$ maka besarnya koefisien determinasi adalah :

$$
\begin{aligned}
\mathrm{D} & =\mathrm{R} 2 \times 100 \% \\
& =0,515 \times 100 \% \\
& =51,5 \%
\end{aligned}
$$

Koefisien determinasi $51,5 \%$ berarti pengaruh Proses Pemberian Pembiayaan dan Preferensi sebesar $51,5 \%$, sedangkan sisanya $100-51,5 \%=48,5 \%$ dipengaruhi oleh faktorfaktor lain yang tidak diteliti.

\section{Pembahasan}

Pengaruh Proses Pemberian Pembiayaan terhadap Kepercayaan Nasabah di PT. Bank Pembiayaan Rakyat Syariah Fajar Sejahtera Bali

Berdasarkan hasil analisis dengan melihat hasil uji t penelitian ini menunjukkan pengaruh antara Proses Pemberian Pembiayaan terhadap kepercayaan di PT. BPRS Fajar
Sejahtera Bali. Dengan menunjukkan hasil signifikansi X1 $0,037<0,05$ dimana nilai signifikansi ini kurang dari nilai alpha 0,05 maka $\mathrm{H}_{\mathrm{o}}$ ditolak dan $\mathrm{H}_{\mathrm{a}}$ diterima. Untuk $\mathrm{t}_{\text {hitung }}>$ $\mathrm{t}_{\text {tabel }}$ yaitu 2,141>1,671 maka $\mathrm{H}_{\mathrm{o}}$ ditolak dan $\mathrm{H}_{\mathrm{a}}$ diterima. Hal ini berarti variabel Proses Pemberian Pembiayaan berpengaruh secara parsial terhadap variabel Kepercayaan Nasabah.

Dalam proses pembiayaan, beberapa prosedur yang harus dijalani meliputi persiapan analisis dan tahap pengambilan keputusan pembiayaan. Prosedur ini tersusun secara sistematis guna mengurangi resiko yang mungkin terjadi. Dalam hal pembiayaan yaitu mengajukan pembiayaan dengan syarat-syarat yang diajukan dan fotocopy jaminan, fotocopy slip gaji bagi yang bekerja untuk bahan analisis, dan bagi pengusaha di survey oleh marketing dimana tempat usaha dan usaha apa yang dijalankan setelah itu dianalisis, tugas menganalisis yaitu komite pembiayaan untuk menganalisis layak atau tidak nasabah diberikan pembiayaan, setelah itu lalu diakadkan dengan bagian legal, lalu akad keputusan di input di sistem dan terakhir dana masuk di simpanan.

Pengaruh Preferensi terhadap Kepercayaan Nasabah di PT. Bank Pembiayaan Rakyat Syariah Fajar Sejahtera Bali

Berdasarkan hasil analisis, penelitian ini menunjukkan pengaruh antara preferensi terhadap kepercayaan di PT. BPRS Fajar Sejahtera Bali. Pada rumusan masalah yang kedua, dengan menunjukkan hasil signifikansi $\mathrm{X} 20,000<0,05$ dimana nilai signifikansi ini kurang dari nilai alpha 0,05 maka $\mathrm{H}_{\mathrm{o}}$ ditolak dan $\mathrm{H}_{\mathrm{a}}$ diterima. Untuk $\mathrm{t}_{\text {hitung }}>\mathrm{t}_{\text {tabel }}$ yaitu 5,626 $>$ 1,671 maka $\mathrm{H}_{\mathrm{o}}$ ditolak dan $\mathrm{H}_{\mathrm{a}}$ diterima. Hal ini berarti variabel Preferensi berpengaruh secara parsial terhadap variabel Kepercayaan Nasabah.

Dalam penilaian pemberian pembiayaan di PT. BPRS Fajar Sejahtera Bali dimana prinsip tersebut yaitu character, capacity, capital, condition, dan collateral. Dari sisi analisis di atas maka pelaksanaan proses pemberian pembiayaan di PT. BPRS Fajar Sejahtera Bali telah sesuai dengan ketentuan yang berlaku. Ini dilihat dari tata cara pelaksanaan sampai dengan proses penerapannya.

Pengaruh Proses Pemberian Pembiayaan dan Preferensi terhadap Kepercayaan 
Nasabah Pembiayaan Multijasa di PT. Bank Pembiayaan Rakyat Syariah Fajar Sejahtera Bali

Berdasarkaan hasil uji regresi linier berganda, diketahui bahwa variabel independen yang terdiri dari Proses Pemberian Pembiayaan (X1) dan Preferensi (X2) secara simultan atau secara bersama-sama ada pengaruh yang signifikan terhadap Kepercayaan Nasabah Pembiayaan Multijasa di PT BPRS Fajar Sejahtera Bali. Hasil olah data menggunakan SPSS versi 24 ditemukan hasil penelitian bahwa uji regresi linier berganda ditemukan $\mathrm{Y}=\mathrm{a}+\mathrm{b}_{1} \mathrm{X}_{1}+\mathrm{b}_{2} \mathrm{X}_{2}+\mathrm{e}$ adalah $\mathrm{Y}=5,719+0,134 \mathrm{X}_{1}+0,634 \mathrm{X}_{2}+\mathrm{e}$ artinya variabel independen (Proses Pemberian Pembiayaan dan Preferensi) mempunyai pengaruh yang positif terhadap variabel dependen (Kepercayaan Nasabah) sebesar 5,719 .

Koefisien regresi dari Preferensi adalah sebesar 0,634. Artinya setiap kenaikan tingkat Preferensi sebesar 0 poin maka Kepercayaan Nasabah akan mengalami kenaikan sebesar 0,634. Begitu juga sebaliknya, apabila Preferensi mengalami penurunan sebesar 0 poin maka Keepercayaan Nasabah akan mengalami penurunan sebesar 0,634 . Untuk melihat pengaruh secara simultan ini dapat dilihat dari hasil uji F. Dari hasil output uji $\mathrm{F}$ hitung $=30,761$ sementara nilai signifikansi didapat sebesar $0,00($ Sig $<0,05)$ jadi dapat disimpulkan bahwa secara simultan atau secara bersama-sama ada pengaruh yang signifikan terhadap Kepercayaan Nasabah Pembiayaan Multijasa di PT BPRS Fajar Sejahtera Bali.

Dari hasil uji koefisien determinasi atau $\mathrm{R}^{2}$ sebesar atau $51,5 \%$. Besarnya nilai koefisien determinasi tersebut menunjukkan bahwa variabel independen yang terdiri dari Proses Pemberian Pembiayaan dan Preferensi mampu menjelaskan variabel dependen yaitu Kepercayaan Nasabah. Sedangkan sisanya $48,5 \%$ (100\% - 51,5\%) dijelaskan oleh faktor lain yang tidak diteliti oleh penulis. Besarnya nilai koefisien determinasi sebesar $51,5 \%$ menunjukkan bahwa variabel dalam model penelitian ini hanya mampu menjelaskan variabel terikat dalam nilai yang tinggi.

Dalam analisis hasil penelitian ini seperti penelitian terdahulu mengenai proses pemberian pembiayaan begitu pula dengan preferensi sama-sama memberi pengaruh positif dan signifikan terhadap kepercayaan nasabah. Proses pemberian pembiayaan yang diterapkan tidak menyulitkan nasabah dengan jangka waktu tersebut sangatlah normal dalam pencairan pembiayaan.

\section{PENUTUP}

Berdasarkan hasil penelitian, analisis data, dan pembahasan mengenai "Pengaruh Proses Pemberian Pembiayaan dan Preferensi terhadap Kepercayaan Nasabah Pembiayaan Multijasa di PT. Bank Pembiayaan Rakyat Syariah Fajar Sejahtera Bali”. Maka dapat diambil kesimpulan sebagai berikut.

Pertama, proses pemberian pembiayaan yang diterapkan tidak menyulitkan nasabah dengan jangka waktu satu minggu atau dua minggu sangatlah normal dalam pencairan pembiayaan. Berdasarkan uji regresi dalam uji t variabel $\mathrm{X} 1$ yang dilakukan dapat disimpulkan bahwa diperoleh probabilitas Sig sebesar 0,037. Nilai Sig < 0,05 $(0,048<0,05)$ dan nilai $\mathrm{t}_{\text {hitung }}>\mathrm{t}_{\text {tabel }}(2,141>$ 1,671) maka variabel Proses Pemberian Pembiayaan (X1) ada pengaruh yang signifikan terhadap Kepercayaan Nasabah Pembiayaan Multijasa di PT BPRS Fajar Sejahtera Bali.

Kedua, berdasarkan uji regresi dalam uji t variabel X2 diperoleh probabilitas Sig sebesar 0,000. Nilai Sig 0,05 $(0,000<0,05)$ dan nilai $t_{\text {hitung }}>t_{\text {tabel }}(5,626>1,671)$ maka variabel Preferensi (X2) ada pengaruh yang signifikan terhadap Kepercayaan Nasabah Pembiayaan Multijasa di PT BPRS Fajar Sejahtera Bali.

Ketiga, Berdasarkan hasil uji regresi dalam uji $\mathrm{F}$ yang dilakukan dapat disimpulkan bahwa diperoleh nilai probabilitas Sig sebesar 0,000 . Nilai Sig $<0,05(0,000<0,05)$ atau $\mathrm{f}_{\text {hitung }}>\mathrm{f}_{\text {tabel }}(30,761>2,76)$, artinya variabel Proses Pemberian Pembiayaan (X1), Preferensi (X2) secara simultan atau secara bersama-sama ada pengaruh yang signifikan terhadap Kepercayaan Nasabah Pembiayaan Multijasa di PT BPRS Fajar Sejahtera Bali.

Dalam kesempatan ini, penulis ingin memberikan saran yang bersifat membangun untuk pengaruh proses pemberian pembiayaan dan preferensi terhadap kepercayaan nasabah pembiayaan multijasa di PT. Bank Pembiayaan Rakyat Syariah Fajar Sejahtera Bali, yakni senantiasa meningkatkan kembali manajemen dalam hal proses pemberian pembiayaan sehingga pembiayaan di PT. 
BPRS Fajar Sejahtera Bali dapat semakin meningkat dan lebih banyak diminati oleh masyarakat luas sehingga nasabah semakin mudah dalam pemahaman proses yang diberikan dan lebih efisien dalam diterapkannya. Diharapkan Pihak PT. BPRS Fajar Sejahtera Bali hendaknya lebih tegas dan selektif dalam pemberian proses pemberian pembiayaan dan lebih berupaya untuk meninggatkan preferensi nasabah serta selalu menjaga kepercayaan nasabah dalam mengambil pembiayaan multijasa di PT. BPRS Fajar Sejahtera Bali.

\section{DAFTAR RUJUKAN}

Ghozali, Imam. Aplikasi Analisis Multivariate dengan Program IBM SPSS. (Yogyakarta: Universitas Diponegoro, 2012) h, 98

Ghozali, Imam. Aplikasi Analisis Multivariate dengan Program IBM SPSS 21 Update PLS Regresi. (Semarang: Badan Penerbit Universitas Diponegoro,2013), h. 98

Handy, For Rich Marketing PT. BPRS Fajar Sejahtera Bali, Wawancara Pribadi, Denpasar 24 September 2020

Mirchandani, Alqur'anku Dengan Waqaf Ibtida Tajwid Blok Warna, (Jakarta: Lautan Lestari), h. 106

Mulyadi, Sistem Akuntansi, Edisi ke-3, Cetakan ke 5. (Jakarta: Penerbit Salemba Empat, 2010), h. 5

Narko. Sistem Akuntansi. Edisi 5. (Yogyakarta: Yayasan Pustaka Nusantara, 2007), h. 3

Sahid Raharjo "Cara Melakukan Uji Reabilitas Alpha Cronbach's dengan SPSS" (http://www.spssstatistik.com/2014/01/ujireliabilitas-alpha-spss.html diakses 24 Juni 2020)

Sugiyono. Metode Penelitian Kuantitatif, Kualitatif, dan R\&D. (Bandung : Alfabeta, CV, 2017), h. 62 